DOI $10.51558 / 2490-3647.2021 .6 .3 .81$

UDK 792(497.6 Sarajevo)“1992/1995“

Primljeno: 30. 04. 2021.

Pregledni rad

Review paper

\title{
Aida Čopra
}

\section{PLESATI U RATU. PERCEPCIJA POZORIŠTA U RATNOM SARAJEVU (1992-1995): PIPPO DELBONO, GIORGIO STREHLER I PETER SCHUMANN}

\begin{abstract}
„Kada sam otišao u Sarajevo, sreo sam jednog dječaka“, priča nam Pippo Delbono. Razgovarali su, i dječak mu je u jednom trenutku rekao: „Vidio sam jedan cijeli grad u ljutnji. Vidio sam ljude koji postaju čudovišta“. A Delbono mu je odgovorio: „I ja sam vidio ljude koji me gledaju kao da sam čudovište. I sve stvari koje se pretvaraju u monstruoznost“. Putovanje, za Delbona, jeste životno iskustvo koje se u isto vrijeme pretvara i u ono pozorišno. Godine 1998. Delbono stvara predstavu Rat. Priča o dječaku kojeg sreće tokom svog putovanja u Sarajevo jeste uvod u Delbonov magični svijet pozorišta kroz koji izražava potrebu da predstavi život koji se rađa iz patnje, bolesti, rata, ali u kojem i dalje ,plešemo“. Danzare nella guerra, ,plesati u ratu“, za Delbona znači suprostaviti ratu ljepotu, radost i poetičnost pokreta.
\end{abstract}

Godine 1995. Giorgio Strehler režira predstavu Majka hrabrost Sarajeva na osnovu teksta Bertolta Brechta. Za Strehlera, Majka hrabrost Sarajeva nije samo predstava, ona je simbol, politički čin koji prikazuje rat kao ljudski neuspjeh. Strehler je svoju viziju pozorišta zasnivao na Brechtovom epskom pozorištu. Godinu dana prije, 1993. godine, sa svojom marionetskom trupom Hljeb i lutka (The Bread and Puppet) Peter Schumann dolazi u Sarajevo da pruži svoju podršku.

Na prvom mjestu želimo pokazati na koji način se Delbonova koncepcija pozorišta i iskustvo tokom putovanja u Sarajevo isprepliću sa primarnim ciljem sarajevskog pozorišta tih godina, kao „duhovnog otpora“, „duhovne potrebe“, „poziva da se liječe ranjene duše“, jednog „natpozorišta“, kako ga naziva Izudin Bajrović, u kojem su i pozorište i život bili i jedno i drugo. Kroz Strehlerovo pozorište, njegov odnos sa Sarajevom i brisanje ,četvtog zida“, govorit ćemo o pozorištu kao pronalasku onih vječnih ljudskih vrijednosti, ali i povrataku u humano pozorište. 
Na trećem mjestu, kroz Schumannov rad pokazat ćemo na koji način se isprepliće vanjska pozorišna stvarnost s onom unutrašnjom kao odlikom snažne političke angažovanosti.

Ključne riječi: savremeno pozorište; Delbono; Strehler; Schumann; pozorište u ratnom Sarajevu; epsko pozorište; političko pozorište

\section{PIPPO DELBONO: PLESATI U RATU}

„Kada sam otišao u Sarajevo, sreo sam jednog dječaka s kojim sam se malo sprijateljio i malo smo porazgovarali u jednom kafiću. I on mi je rekao: „Vidio sam željezo. Spaljeno. Slomljeno. Željezo koje postaje ranjivo kao meso. Vidio sam gomilu metaka. Kamenja. Spaljenog kamenja. Kamenja koje eksplodira. Rupe od metaka na svim zidovima. Vidio sam ljude koji čekaju satima u redu za vodu, na minus dvadeset stepeni, na meti snajperista. Vidio sam djecu na ulici, otkinute glave. A ti, ti nisi ništa vidio“.

A ja sam mu rekao: „I ja sam, u svojoj zemlji - a nije bio rat - vidio bolnicu, bolesne ljude, užasne tragove na koži, kosu, spaljenu kosu, rane“.

A on: „Vidio sam jedan cijeli grad u ljutnji. Vidio sam ljude koji postaju čudovišta“.

A ja: „I ja sam vidio ljude koji me gledaju kao da sam čudovište. I sve stvari koje se pretvaraju u monstruoznost. Vidio sam da sam postajao čudovište. Da sam mogao ubiti. Da sam se mogao ubiti. Ali bilo me je strah, kao tebe“.

„Porodice protiv porodica u Sarajevu. Braća protiv braće u Sarajevu“, rekao mi je.

Ja sam bio sam, snažan. Rekli su mi: „Vi ste već skoro mrtvi“.

„Deset hiljada mrtvih u Sarajevu. Osamdeset hiljada ranjenih. Narodi protiv naroda. Rase protiv rasa. Klase protiv klasa. Kaste protiv kasta. Porodice protiv porodica. Braća protiv braće“, rekao mi je, „u Sarajevu“.

A ja sam mu rekao: „Ne želim više ništa znati o ratu. Vidio sam sliku u jednoj knjizi. To je bila Hirošima. Bila je u potpunosti prekrivena cvijećem“ (Delbono 2004a: 167-168).

Priča o dječaku kojeg Delbono sreće tokom svog putovanja u Sarajevo jeste uvodni monolog u njegovoj predstavi Rat (Guerra) koja je nastala 1998. godine, ali ona može biti i uvod u našu temu kroz koju želimo da predstavimo smisao i ulogu pozorišta u kontekstu jedne okrutne gradske stvarnosti koja je pronašla način da govori i da utječe ne samo na život unutar njenih granica već i izvan njih, da nađe svoje mjesto ne samo na lokalnoj sceni već i na onoj internacionalnoj. 
Sa predstavom Rat Debono je želio proširiti temu rata već prisutnu u predstavi Skitnice (Barboni), nastaloj 1997. godine u Italiji, a iste godine predstavljenoj i sarajevskoj publici. Rat je na neki način nastavak Skitnica u kojima Delbono priča priču o svom unutrašnjem ratu, o ratu protiv svojih vlastitih demona. Sa Ratom, inspirisanim životom u ratnom i poslijeratnom Sarajevu, Delbono je želio ,prošiti temu unutrašnjeg rata, onog koji se rađa u unutrašnjosti čovjeka, na temu ratova koji se rađaju među ljudima“" (Delbono 2004a: 173).

U Sarajevu je, kaže Delbono, sreo dječaka koji je koristio slikovit opis rata koji je zatim Delbono preuzeo kako bi napisao tekst. Ali ono što je u Sarajevu po prvi put shvatio i što je označilo potpuno novi period u njegovom životu jeste osjećaj boli „koja se nije odnosila na [njegovu] vlastitu smrt, već na smrt drugih, smrt ljudi koje [nije] poznavao" (Delbono 2004a: 173).

Delbonovo pozorište je, kako ga je definisao Baptiste Pizzinat, „,svako mjesto života na kojem možemo pronaći hrabrosti da gledamo jedni druge“" (2012: 155), tj. u svijetu ,u kojem je sve fikcija, politika, društvo, moda, televizija... “ (Delbono 2004b: 80), Delbono traži ,život u pozorištu“ (2004b: 80). Radeći sa netipičnim glumcima koji imaju socijalne ili zdravstvene poteškoće ${ }^{1}$, Delbono istražuje i postavlja na scenu druge forme pozorišnog stvaralaštva s ciljem da u boli pronađe nevjerovatnu energiju života. U tom pogledu Delbonovo pozorište se približava konceptu Artaudovog pozorišta okrutnosti: ,ideja o pozorištu koja vrijedi samo kroz magičnu, jezivu vezu sa stvarnošću i opasnošću“ (Artaud 1938: 95).

Glumac za Delbona je stvaralac, créateur, koji u isto vrijeme „,mora postati režiser samoga sebe“. „Naravno, [...] moramo uzeti ratne okolnosti u kojima su se predstave igrale“, kaže Izudin Bajrović u Svjedočanstvima.

„Nekako je granica između pozorišta i života bila izbrisana. Pitanje je šta je bilo veće „pozorište“, život ili samo pozorište? Šta je bilo teatralnije? Život je postajao pozorište, tragično pozorište, a pozorište je postajalo život. [...] Mi smo jednostavno stvarali pozorište. Glumiti, igrati, učestvovati iz neke najdublje životne potrebe i sve ono što je moj život prenijeti na scenu, i ne namjerno, nego se to jednostavno tako dešavalo [...]. To je bila suština pozorišta, a i života u kojem smo se našli““ (Bajrović u Diklić 2017: 29).

Svoju trupu Pippo Delbono je osnovao 1986. godine zajedno sa argentiskim glumcem Pepeom Robledom. Sačinjavaju je profesionalni glumci zajedno sa glumcima amaterima koje je Pippo susretao u različitim periodima života: Nelson, beskućnik; Armando koji boluje od dječije paralize; Gianluca rođen s Downovim sindro mom; i Bobò koji je bio gluhonijem i bolovao od mikrocefalije. Svoju posljednju predstavu, Sreća (Gioia 2019) Delbono posvećuje Bobu koji umire iste godine. 
Dječak kojeg je Delbono sreo u Sarajevu jeste metonimija stvarnosti tokom rata, ne samo one društvene i političke, već i one umjetničke. On može simbolizirati i samog glumca, jer kako kaže Delbono: „upravo su živa bića ta koja želim da vidim na sceni“ (2004a: 100). Glumci, u gradu pod opsadom koji i sam postaje theatron „u kojem prirodno igramo ljudsku komediju“ (Chaudoir 2008: 190), traže život u pozorištu, život koji se rađa iz patnje, bolesti, rata, ali u kojem i dalje plešemo. To je ono što je osnova i za stvaranja predstave Sklonište, u režiji Dubravka Bibanovića, premijerno izvedene 1992. godine u tek osnovanom Sarajevskom ratnom teatru. „Sklonište nije bila priča o strahoti rata, nego o grotesknosti rata" (Bečić u Diklić 2017: 35). Nastala na osnovu tragikomičnih priča običnih ljudi o njihovoj svakodnevnici, koje je Bibanović susretao u skloništu, u Kabareu Pozorišta mladih, predstava je bila, kako kaže glumica Emina Muftić, prilika da se na sceni igra život ne samo tih običnih ljudi, već i život onih koji su stvarali predstavu². Predstava je nastala iz života, a život je pronašla na sceni; ideja za koju možemo vezati Foucaultovu estetiku postojanja, „to je ideja na osnovu koje sama umjetnost mora da uspostavi sa stvarnošću odnos koji se ne zasniva na ukrasu, imitaciji, već na ogoljavanju, demaskiranju, razotkrivanju, iskopavanju, brutalnom svođenju na suštinu postojanja“ (Foucault 2009: 173); a to je ono što je i u osnovi Delbonove poetike. „Mislim da smo se nalazili u jednom ogoljelom trenutku“, kaže redateljica Aida Begić, „znači u trenutku gdje je zaista život sam bio suština“" (Begić u Diklić 2017: 39).

Danzare nella guerra, ,plesati u ratu“ (Delbono 2004a: 177), za Delbona znači suprostaviti se ratu i kroz umjetnost prikazati sve njegove kontradikcije. „U Sarajevu, mnogo ljudi je umrlo nakon završetka rata. Objasnili su mi da su neki imali rak, npr., i da su se tokom rata borili da se tome odupru; ali kada se rat završio, prestali su da se bore i umrli su“ (Delbono 2004a: 177). „Pozorište je borba protiv smrti i [...] treba poći od smrti da bi se kretalo prema životu“ (2004a: 177), kaže Delbono, „Rat počinje smrću i progresivno pronalazi život“ (2004a: 175). „Plešimo, inače smo izgubljeni“, poznate su riječi njemačke koreografkinje Pine Bausch, velike Delbonove inspiracije. Klimaks predstave Rat je scena u kojoj se glumci kreću uz muziku nijemog filma. Razrađena samo nekoliko dana prije premijere, Delbono je tu scenu htio izbaciti, ali kada je vidio koliko života ona u sebi nosi, ostala je. Ples u Delbonovim predstavama, „postaje spontani ples glumca sretnog što postoji“ (Purkhardt 2009: 127), a ljepota njegove umjetničke forme ogleda se u „neravnoteži, čistoći pokreta,

Godine 1997., povodom obilježavanja 25. godina od osnivanja Sarajevskog ratnog teatra, prikazan je dokumentarni film Sklonište, u režiji Emira Kapetanovića, baziran na sjećanjima kreativnog tima koji je učestvovao u stvaranju predstave. 
nevinosti pogleda, velikodušnosti prisustva“"(Purkhardt 2009: 126). Svi elementi njegovih predstava uvijek nose karakteristike ,anegdote u alegoriji, politike u poetičnosti, klasičnog u narodnom, tragedije u komičnom“ (Purkhardt 2009: 127).

U predstavi Nakon borbe (Dopo la battagia), nastaloj 2011. godine, s temom političke i kulturne licemjernosti, unutrašnjih i vanjskih sukoba i ludosti, Delbono kaže: „Zadovoljan sam, vidim, plešem, smijem se, pjevam“. Pa tako je i Sklonište „otkrilo jedan mikrosvijet ljudskog u tom skloništu gdje su se stradalnici, patnici, našli u situaciji koja je teatarskim sredstvima pretvorena u proslavu života“ (Bosto u Diklić 2017: 54).

„Sanjala sam jedan san. Prisustvovala sam probama Pine Bausch: scena je bila sva crna i siva, a pred scenom se nalazio jedan fotograf koji je slikao Polaroid kamerom. Ali na jednoj od slika koja se razvijala, nije bilo te sive scene, već prelijepi vrt. Odmah je fotograf počeo pokazivati svima sliku uzvikujući: „Kako je ovo moguće, na sceni ne postoji vrt?“. Potom je stigla Pina i ne rekavši ništa pogledala je scenu i ja sam vidjela da se u njenim očima odražavao taj vrt“.

Radi se o monologu iz predstave Nakon borbe. Tekst izgovara snimljeni ženski glas. Delbono je sam na sceni, s mikrofonom i papirom u ruci, scena je siva i prazna. Nakon posljednje izgovorene rečenice, Delbono iznosi buket crvenih ruža i spušta ih na proscenijum. Čuje se muzika sefardske pjesme „Adio Querido“, a dvije glumice u crvenim haljinama izlaze na scenu i počinju ,spontano“ plesati sa Delbonom. Plesati u ratu znači pretvoriti sivilo i prazninu scene u vrt s cvijećem. Na taj način se Delbonova koncepcija pozorišta i iskustvo tokom putovanja u Sarajevo isprepliću sa primarnim ciljem sarajevskog pozorišta tih godina: glumci su plesali u ratu, a zajedno sa njima i publika, u jednom natpozorištu, kako ga naziva Izudin Bajrović, u kojem su i pozorište i život bili i jedno i drugo.

\section{RUŠIMO ZIDOVE}

U Palermu, ispred kuće gdje je Mafija 1992. godine ubila suca Paola Borsellina, Giorgio Strehler šalje buket crvenih ruža Borsellinovoj majci Mariji prilikom održavanja javnog govora koji je prethodio premijeri njegove predstave Majka hrabrosti Sarajeva (Madre coraggio di Sarajevo) na osnovu teksta Bertolta Brechta. Govor je održan 28. juna 1996. godine, a čitala ga je, u Strehlerovo ime, glumica Giulia Lazzarini u siromašnoj odjeći građanke Sarajeva. 


\begin{abstract}
„Ovo nije predstava, ovo je simbol. Odbrana naše kulture kao osnovnog akta naše države, odbrana naše kuće i kuće svih onih koji rade u italijanskom pozorištu. Tekst Majka hrabrosti Sarajeva Bertolta Brechta [...] je i simbol i djelo koje govore o našoj tragičnoj sposobnosti da nastavljamo da ratujemo i da živimo sa ratom. Rat je znak ljudskog neuspjeha. Sarajevo je simbol. Sarajevo je svugdje gdje ljudi ubijaju druge ljude“" (Strehler 1996; Arhiva Piccolo Teatro).
\end{abstract}

Od 1956. godine Strehler počinje detaljno izučavati Brechtovo pozorište i postavlja na scenu veliki broj njegovih tekstova: Prosjačka opera (1956), Dobri čovjek iz Sečauna (1958), Schweik u Drugom svjetskom ratu (1960) i Život Galilea (1963). Jedan od osnovnih Brechtovih pristupa koje Strehler preuzima jeste onaj po kome pozorište mora ispuniti društvenu odgovornost i učiniti da publika učestvuje u pozorišnom ritualu odbijajući ideju po kojoj je pozorište stvarnost odvojena od života. To su principi Brechtove integralne transformacije pozorišta: ,morat ćemo prirodno napustiti pojam četvrtog zida, tog fiktivnog zida koji razdvaja scenu od sale i stvara iluziju da se proces koji se prikazuje odvija u stvarnosti bez pristustva publike“" (Brecht 1972: 331).

Strehler počinje opsesivno „tražiti kritičko učešće gledaoca, ali ne odustajući nikad od njegovog emocionalnog uplitanja“" (Bosisio 2017: 54).

„Ono što me je Brecht naučio [...] i što me i dalje uči, jeste jedno ljudsko pozorište, bogato, u potpunosti pozorište, [...], ali koje ne predstavlja krajnji cilj, koje nije samo pozorište. Pozorište stvoreno za ljude da se zabave, ali isto tako da im pomogne da se promijene i da pretvore svijet u jedan bolji svijet, u svijet za čovjeka. Biti glumac i čovjek pozorišta, ali postojati i kao svjesan i odgovoran pojedinac. Mogućnost da se živi integrirajući ova dva ljudska plana u isto vrijeme i sa istim intenzitetom. Ne radi se o pozorištu izvan historije, izvan vremena, ne radi se o vječnom pozorištu, ne radi se o historiji protiv pozorišta, već o historiji i pozorištu, svijetu i životu u isto vrijeme, u stalnom dijalektičkom odnosu, teškom, ponekad tužnom, ali uvijek aktivom, uvijek usmjerenom na sveopće postojanje“ (Strehler 1980: 121).

Dva Strehlerova gospodara: ,pozorište i život“, kako ih je definisala Danelle Zana (1991) u optici Brechtovog epskog pozorišta, bili su neophodni da bi njegova poetika živjela. Zbog toga je i predstava Majka hrabrosti Sarajeva nastala kao veza između historije i pozorišta, kao politički čin koji prikazuje rat kao ljudski neuspjeh. Prikazana u ulici D'Amelio gdje je Borsellino ubijen, postaje neminovno uronjena u historiju, ne samo historiju Italije, već i Sarajeva, jer je ulica D’Amelio, „kao i Sarajevo, projekcija svih mjesta na kojima čovjek diže ruku na čovjeka“"(Ovadia 1996), kaže 
glumac predstave, Moni Ovadia. Sjetimo se riječi dječaka kojeg Delbono sreće u Sarajevu: „Vidio sam jedan cijeli grad u ljutnji. Vidio sam ljude koji postaju čudovišta“. Godine 1992. počinje rat u Sarajevu, 1992. je ubijen Borsellino, 1995. završava rat, 1995. Strehler stvara predstavu.

Godine 1993. u Kamernom teatru 55 izvedena je predstava Dine Mustafića Zid, na osnovu Sartreove novele. Mustafić kaže da je izabrao temu Španskog rata jer su „situacije iz tog rata i iz našeg, Bosanskog rata, imale mnogo analogije. Tada se dogodilo po prvi put da su nevjerovatna mržnja i nasilje rukovodili grupu ljudi na uništenje ostalih isključivo bazirano na toj mržnji“ (Mustafić u Diklić 2017: 169). Strehler je izabrao da kroz Brechtov tekst govori o borbi i ljutnji, o Sarajevu kao simbolu ne samo jednog krvavog rata, već i rata u Palermu i svih krvavih ratova koji su izazvali bol i očaj. Mustafić bira Sartrea: „onda smo u scenografskom rješenju željeli da taj zid predstavlja tjeskobu koja vrši presiju na sve, tako da je zid trebao da se kreće tokom predstave i da u različitim situacijama pravi različitu strukturu prostora“ (Mustafić u Diklić 2017: 170). S obzirom da je u ratu bilo nemoguće naći drvo kao materijal za scenografiju, Mustafić je dobio, za gradnju njihovog zida, drvo od kojeg se prave mrtvački sanduci od preduzeća Pokop.

„U tom smislu se naša stvarnost, takva kakva je bila - surova, svaki dan se ginulo i sahranjivalo, smrt je bila sastavni dio našeg svakidašnjeg života - potpuno pomiješala sa stvarnošću naše predstave. Meni kao reditelju nije bilo teško objasniti glumcima šta u stvari igramo, šta je metafora komada i kako preskočiti tu smrt; to je ono sartrovsko preskakanje egzistencije: kako spoznati slobodu? Kako do te slobode doći?“ (Mustafić u Diklić 2017: 170).

Ljubica Ostojić kaže za ovu predstavu da su taj zid svi osjećali. „Ta predstava je bila na rubu podnosivosti uopće da se gleda, toliko je tu bilo jedne istine, i scenske, i ljudske, i životne“ (Ostojić u Diklić 2017: 178). I opet se vraćamo na Delbonovu ideju da treba poći od smrti da bi se kretalo prema životu. Zid, kao simbol zatvorenog prostora, mentalnog ili fizičkog, ali i zid kao dio scenografije doniran od Pokopnog društva, odražava upravo ono što je Strehler preuzeo od Brechta: pozorište i život koji su u stalnom dijalektičkom odnosu, teškom, ponekad tužnom, ali uvijek aktivnom, uvijek usmjerenom na ljudsko postojanje. Zid je predstavljao nadu u pronalazak onih vječnih ljudskih vrijednosti, ali i povratak u humano pozorište, u potpunosti pozorište, koje veže historiju i pozorište i svijet i život. Uvijek se radi o zidu koji se treba srušiti, onom Delbonovom koji se često odnosi na predrasude, stereotipe i diskriminaciju, ali i onom koji sprečava političku i društvenu demistifikaciju, kao u Strehlerovoj Majci hrabrosti, ili onom Brechtovom koji se 
treba ukloniti da bi pozorište sačuvalo „određeni zemaljski i prozaični karakter koji navodi na razmišljanje“ (Brecht 1972: 356).

\section{KRIK SARAJEVSKOG HAPPENINGA}

„Samo jedan pogled na običnu publiku“, kaže Peter Brook, „,daje nam neodoljivu želju da je prodrmamo - naprije to učiniti, a onda postavljati pitanja. To je ono što vodi ka happeningu. [...] Iza happeninga je krik: Probudite se!“ (1977: 78). Godine 1994. Peter Schumann dolazi u Sarajevo sa svojom marionetskom trupom Hljeb $i$ lutka (The Bread and Puppet) i izvodi predstavu Cirkus Veliko stopalo na otvorenoj sceni ispred Narodnog pozorišta. Osnovana 60-ih godina prošlog stoljeća, trupa će uvijek nastojati da scenu pretvori „u prolepsu revolucije“ (Puppa 2018: 34), a njihov rad će biti usmjeren na promjenu društvenih struktura i mentaliteta obraćajući se ljudima koji inače nemaju naviku da idu u pozorište. Miješajući tradiciju i savremene elemente narodne kulture, Schumann se suprostavlja kapitalističkom konzumerizmu i buržujskom društvu koji ga potvrđuje. Već 1968. godine, njegova trupa na Festivalu Radikalnog pozorišta u San Francisku izlazi na ulicu kako bi stvorila urbani happening s ciljem da se direktno obrati ljudima u njihovom svakodnevnom životu. Tretirajući društveno-politički angažovane teme i inspirišući se „vašarskim paradama, komedijom dell'arte, putujućim trupama Dalekog istoka“", Schumann izvodi predstave „svugdje gdje se ljudi okupljaju: crkve, fabrike, sportske dvorane“, odbijajući da „se obraća publici definisanoj kao skup ljudi koji su platili svoja mjesta“" (Simon 1970: 1140). Njegovo pozorište je uvijek „,sredstvo društvene kritike podobno da pretvori gledaoce u glumce revolucije“ (ibidem, 1137).

Veliki broj Schumannovih predstava predstavlja borbu protiv rata, nepravde, represije i imerijalističke politike. Godine 1966. Schumann stvara kratku predstavu uličnog pozorišta Čovjek kaže majci zbogom (Man Says Good Bye to His Mother), u kojoj u ulozi pripovjedača, na jednostavan način, upotrebljavajući samo nekoliko riječi, priča priču koja aludira na Vijetnamski rat:

„Pripovjedač kaže: „Djeca se plaše. Sakrivaju se iza svoje majke“. Pruža lutku majci Vijetnamki koja počinje da je ljulja. Pripovjedač kaže: „Čovjek uzima svoj avion i traži neprijatelja. Bombarduje djecu“. [...] Pripovjedač kaže: „Djeca umiru“. Žena spušta lagano lutku na zemlju. Pripovjedač kaže: „Žena uzima makaze i napada čovjeka“. [...] Žena se saginje da uzme makaze, uspravlja se i diže ruku kako bi napala čovjeka. Pripovjedač uzima ženinu ruku kako bi je 
usmjerio, i ona počne udarati čovjeka po leđima. Pripovjedač kaže: „I ona ga ubi. [...] I čovjek umre“. Čovjek pada. Čuju se tri udarca o veliki bubanj“" (Nichet 2013: 875).

Predstava je posvećena majkama Istočnog Harlema koje su pustile svoje sinove u Vijetamski rat kako bi izbjegle nezaposlenost i diskriminaciju. Godine 1968. Shumann preuzima ovu uličnu scenu i na osnovu nje stvara predstavu Ponavljanje (Reiteration). U ovoj novoj verziji čovjeka ne ubijaju makazama, već izlazi pred sud, biva proglašen krivim i smaknut.

I u predstavi Vatra (Fire, 1965), u kojoj učestvuje pet glumaca i petnaest lutaka, svi pod maskama i obučeni na isti način - jer su „,marionete bučnije od auta“ (Schumann u Nichet 2013: 874) - Schumann odaje počast žrtvama Vijetnama. „Prva živa slika podsjeća na bdenje nad pokojnikom u potpunosti nepomično, a zatim, nakon duge tišine, nekoliko glumaca se počinju neprimjerno kretati u tišini“" (Nichet 2013: 876). Gotovo sve predstave u kojima Schumann tretira temu rata nose teret tuge, crnine, boli, i potrebe da se kroz mučni krik prodrmaju široke mase; ali kada dolazi u Sarajevo, 1994. godine, odlučuje da na otvorenoj sceni postavi cirkus, sinonim jednostavne zabave i radosti. Shumann kaže da je imao namjeru da na drugačiji način pristupi temi rata i okrutnoj stvarnosti, da ponudi Sarajevu veseli happening. Plato ispred Narodnog pozorišta postaje cirkusna pozoronica šarenih kostima, maski, muzike i umjetnih konja. U predstavi su učestvovali glumci i studenti Režije Akademije scenskih umjetnosti u Sarajevu. Cirkus je zapravo druga predstava koju Shumann realizuje u Sarajevu:

„Te godine [1994] je Piter Šuman došao u Sarajevo [... ]. Radili smo sa njim Oratorij uskrsnuća. To je bila jedna dosta jednostavna predstava u prostorima MESS-a, a osnov za predstavu bio je američki ustav i nama mladim ljudima je bilo interesantno da se igramo sa nepravilnostima američke politike. Piter Šuman je vrlo dobro znao šta i zašto je to radio. Na kraju smo napravili jednu vrlo lijepu predstavu [...]. Nakon toga je Piter Šuman došao sa Cirkusom i to je bilo opet jedno predivno iskustvo, radeći teatar koji mi nismo imali prilike raditi u Sarajevu. To je bio pravi teatarski cirkus i izvođen je na otvorenom, ispred Narodnog pozorišta“ (Begić u Diklić 2017: 41).

Ako uzmemo u obzir razmatranja Jean Cocteaua koji u cirkusu pronalazi isti intenzitet kao i u grčkoj tragediji - Cocteau poredi braću Fratellini sa velikim figurama grčkog pozorišta - onda možemo reći da Schumannov cirkus nije usmjeren da pobudi samo jednostavna osjećanja. Schumannovo pozorište i kad pleše u ratu obraća se „stomaku koji ispušta krik protiv velike gladi svijeta i velike patnje“ (Schu- 
mann u Nichet 2013: 876). „Marionetsko pozorište je pozorište svih mogućnosti. Marionete i maske bi trebale glumiti na ulici. One su snažnije od zvukova saobraćaja. [...] One viču i plešu i udaraju se po glavi i prikazuju život u najjasnijem obliku“ (Schumann 2017).

\section{PRIMARNA FUNKCIJA POZORIŠTA}

Na kraju svake predstave glumci trupe Hljeb i Lutka nude publici komad hljeba koji su prepremili isti dan. „Upravo je komad hljeba taj koji vam damo u isto vrijeme kad i marionetsku predstavu jer naš hljeb i pozorište idu zajedno" (Schumann u Nichet 2013: 874). Paolo Grassi, koji zajedno sa Strehlerom 1951. godine osniva Piccolo Teatro u Milanu, okarakterisao je pozorište kao „kolektivnu potrebu, kao građansku potrebu, kao javni servis, isto kao što su to metro ili vatrogasci“. Mi želimo, kaže Grassi, „da zbog tog veoma dragocijenog javnog servisa stvorenog zbog kolektiva, kolektiv donese potrebne mjere kako bi se pozorište izvuklo iz trenutne ekonomske oskudice i trenutnog monopola nad ograničenim brojem publike, vraćajući mu njegovu staru i istinsku suštinu i funkcije“ (1946). Schumann daje pozorištu još radikalniju ulogu, ono postoje hrana, jedna od primarnih ljudskih potreba. U vrijeme kada Schumann osniva svoju trupu, 1962. godine, svijet je prodrman političkim i društevnim događajima - Maj '68, radnička borba protiv sistema produkcije, pobune studenata, stvaranje ekstremnih ljevica, borba protiv konformizma, feministički pokreti - koji vode do kodifikacije novih vrijednosti. Pozorišna produkcija se razvija unutar tih političkih i društvenih pokreta i postaje instrument analize i kritike svakodnevne stvarnosti u cilju promovisanja novih vrijednosti kao što su to antiautoritarno uređenje, prava čovjeka i ljudsko dostojanstvo. Pozorište teži ka kolektivu, ka negiranju podjele glumac-gledalac, i izlazi na ulice kako bi se direktno obratilo ljudima izvan utvrđenog pozorišnog konteksta.

Politički i društveni konteks nije jedini razlog zbog kojeg se pozorište politizuje i izlazi na ulicu, što može biti metaforički shvaćeno kao pozorište dostupno svim tipovima publike (raditi $n a, s a, u$ ulici). Drugi razlog su novi načini komunikacije, kinematografija prije svega, a zatim televizija. Luigi Allegri objašnjava da je kinematografija počela zamjenjivati pozorište ispunjavajući funkcije koje su historijski uvijek pripadale pozorištu: „pričati nevjerovatne priče, predstaviti proživljenu stvarnost, zabaviti i dirnuti, fascinirati gledaoca vodeći ga na daleka mjesta u vremenu i prostoru“ (2014: 9). Pozorište se sve više udaljava od gledaoca, 
još više zbog činjenice da je televizija kod gledaoca i dopušta mu mentalnu distrakciju. „Scena, nekada pluća, mozak i srce polisa, procesni i kognitivni instrument“, čini se da „više nije potrebna“" (Puppa 2001: 48).

S obzirom da se život u opkoljenom Sarajevu odvijao bez struje, pozorište je bilo gotovo jedina vrsta medija, pa je na neki način po automatizmu povratilo tu svoju primarnu ulogu o kojoj i Grassi govori. A s obzirom da je izlazilo iz svih utvrđenih pozorišnih konteksta, u pogledu načina i mjesta izvođenja predstava, postajalo je neminovno kolektiv i brisalo granice glumac-gledalac.

„Ne samo da smo mi, pozorišni ljudi, funkcionisali kao jedno biće, nego smo mi zajedno sa publikom funkcionisali kao jedno biće, jedan duh. I tu je smisao našeg rada. Mi smo uvijek imali prepune sale ljudi koji su osmišljavali naš rad. Publika je bila dio predstave; čak i više: publika je bila jedan od likova u predstavi“ (Diklić 2017: 30).

Pozorište u opkoljenom Sarajevu je postalo jedna od primarnih potreba. Za Mustafića, ono će imati jednu antropološku funkciju.

„Kao da sam u pozorištu, i kroz pozorište, imao i sačuvao lice, obraz, oči, dušu, i sve ono što je bukvalno napadnuto nasiljem, surovošću ratne logike, zabrana, i svim onim što čovjeka ne čini bićem, ne čini jednakim. Pozorište mi je pomoglo da sačuvam svoju osobenost, s jedne strane, i da ostanem u dubokoj ljudskoj vezi sa drugima, s druge strane. Pozorište je za mene bila jedna vrsta zraka u zagušljivom, klaustrofobičnom prostoru, u jednom sarajevskom autizmu koji smo tada imali, u jednom pravom konclogoru - ona vrsta zraka koja mi je davala osjećaj slobode“ (Mustafić u Diklić 2017: 174-175).

„Razumijeti bol drugog je također jedini način da mu se pomogne, to je otprilike pozorište“ (Delbono 2004a: 175). Ova Delbonova ideja je ono što će ga i navesti da ode u Sarajevo, a kasnije i da stvori predstavu Rat. Rat u zemljama bivše Jugoslavije inspirisat će sociologa Luca Boltanskog da teorizuje, u svom djelu Patnja na daljinu (2007), pitanje pasivnog gledaoca koji vidi i koji zna, ali ne može ništa uraditi. Kada je takav pasivni gledalac umjetnik, posebno podložan da bude dirnut patnjom drugoga i da smatra svojom dužnošću da reaguje, onda on pretvara predstavu kojoj prisustvuje kao nemoćan gledalac u predstavu u kojoj će djelovati kao aktivni glumac. To je i u osnovi Strehlerove namjere da kroz Sarajevo govori o italijanskoj stvarnosti tih godina, ali i u osnovi Schumannovog rada da kroz urbani happening dovede Cirkus u Sarajevo. I Delbono i Strehler i Shumann su težili da ožive pozorište kao jednu od primarnih potreba ljudske svakodnevice, pozorište koje, naročito nakon koncepta Brechtovog epskog pozorišta, preuzima snažnu političku ulogu, nastoji da postavlja 
pitanja o problematikama savremenog čovjeka, i favorizuje uplitanje gledaoca, ili bolje reći svih tipova gledalaca, u dramsku akciju.

U posljednjoj predstavi Radost (Gioia 2019) koju stvara u znak sjećanja na Boba koji je bio dio njegove trupe od 1995. godine, Delbono kaže: „Nikad nisam vidio zimu koja se nije pretvorila u proljeće“. U jednom od posljednjih prizora scena je prekrivena cvijećem - jedan od elemenata koje Delbono preuzima od Pine Bausch iz njene koreografije Nelken - to je ono isto cvijeće koje i kad nije na sceni, odražava se u očima onoga koji tu scenu posmatra, to je i onaj osjećaj slobode o kojem Mustafić govori, to je i onaj isti ples u ratu koji postoji i onda kada razloga za ples nema.

\section{BIBLIOGRAFIJA}

1. Allegri, Luigi (2014), L'artificio e l'emozione, L'attore nel teatro del Novecento, Laterza, Roma - Bari

2. Artaud, Antonin (1938), Le théâtre et son double, Gallimard, Paris

3. Bosisio, Paolo (2017), "Regia e citazione. Il caso di Giorgio Strehler", Parole Rubate, 15, 51-69.

4. Brecht, Bertold (1972), Écrits sur le théâtre, L'Arche Editeur, Paris.

5. Brook, Peter (1977), L'espace vide, Écrits sur le théâtre, Édition du Seuil, Paris.

6. Chaudoir, Philippe (2008), "Art public, arts de la rue, art urbain", Études théâtrales, 41-42, 183-191.

6. Delbono, Pippo (2004a), Mon théâtre, Myriam Blœdé i Claudia Palazzolo, Le Temps du théâtre/ACTES SUD, Arles

7. Delbono, Pippo (2004b), Le Corps de l'acteur ou la nécessité de trouver un autre langage, Les Solitaires intempestifs, Besançon.

8. Foucault, Michel (2009), Le Courage de la vérité. Le Gouvernement de soi et des autres II. Cours au Collège de France, 1984, Hautes Études - Gallimard - Seuil, Paris

9. Nichet, Jacques (2013), Le théâtre n'existe pas, Collège de France

10. Pizzinat, Baptiste (2012), "Pippo Delbono et le courage de la vérité", Jeu, 143, 154-158.

11. Puppa, Paolo (2001), "L'attore et la strada", Trans/Form/Ação, 24, 47-56.

12. Puppa, Paolo (2018), "La Commedia dell'arte e il teatro politico", Rebento, 8 , 4-24. 
13. Purkhardt, Brigitte (2009), "Entre la danse des ténèbres et l'hymne à la lumière, Questo buio feroce (Cette obscurité féroce)", Jeu, 133, 125-127.

14. Simon, Alfred, "Théâtre Et Désastre: Qui Croit Encore Au Théâtre Populaire?", Esprit (1940-), 393 (6), 1136-1156.

15. Strehler, Giorgio (1980), Un théâtre pour la vie, Fayard, Paris.

16. Davor Diklić (ur.) (2017), Teatar u ratnom Sarajevu (1992-1995), Svjedočanstva, MESS, Sarajevo

17. Thomson, Peter (1997), Mother Courage and Her Children, Cambridge University Press.

18. Zana, Danielle (1991), "Giorgio Strehler, poète et serviteur de deux maîtres: le théâtre et la vie", Jeu, 60, 17-22.

\section{Novinski članci i arhiva:}

1. Grassi, Paolo (1946), "Teatro, pubblico servizio", Avanti !

2. Ovadia, Moni (1996), "L'allegoria e la tragedia da Sarajevo a via d'Amelio", La Reppublica, dostupno na: https://ricerca.repubblica.it/repubblica/archivio/ repubblica/1996/06/28/allegoria-la-tragedia-da-sarajevo-via.html [konsultovano 18 . januara 2021]

3. Schumann, Peter (2017), "Notre manifeste artistique", dostupno na: https://laparoleerrantedemain.org/index.php/2017/10/24/8-novembre-cantastoria-dubread-puppet/, [konsultovano 19. januara 2021]

4. Strehler, Giorgio, Archivi, Piccolo Teatro di Milano, dostupno na: https://archivio.piccoloteatro.org/eurolab/index.php?tipo $=4 \& \mathrm{ID}=98 \& \mathrm{imm}=1 \&$ contatore $=0 \&$ real $=0$ [konsultovano 09. januara 2021] 


\title{
DANCING IN WAR. PERCEPTION OF THEATER IN WARTIME SARAJEVO: PIPPO DELBONO, GIORGIO STREHLER AND PETER SCHUMANN
}

\section{Summary:}

„When I went to Sarajevo, I met a boy“, Pippo Delbono tells us. They talked, and suddenly the boy told him, „I saw an entire city in anger. I've seen people become monsters“. And Delbono replied, „And I’ve seen people look at me like I'm a monster. And all the things that turn into monstrosity“. Traveling, for Delbono, is a life experience that turns into a theatrical one at the same time. In 1998, Delbono created a play called War. The story of the boy he meets during his trip to Sarajevo is an introduction to Delbono's magical world of theater through which he expresses the need to present a life that is born from suffering, illness, war, but in which we still „dancing“. Danzare nella guerra, „dancing in the war“, for Delbono means to oppose the war to the beauty, joy, and poetics of the movement.

In 1995, Strehler directed a play called Mother Courage of Sarajevo based on the text written by Bertolt Brecht. For Strehler, Mother Courage of Sarajevo is not just a play, it is a symbol, a political act that portrays war as a human failure. Strehler based his vision of theater on Brecht's epic theater. One year before, in 1993, with his puppet troupe, The Bread and Puppet, Peter Schumann came to Sarajevo to provide his support.

In the first place, we want to show how Delbono's conception of theater and experience during his trip to Sarajevo intertwine with the primary goal of Sarajevo theater in those years, as „spiritual resistance“, „spiritual needs“, „call to heal wounded souls“, a „super theater“, as Izudin Bajrović calls him, in which theater and life were the same. Through Strehler's theater, his relationship with Sarajevo, and the breaking of the „fourth wall“, we will talk about theater as research of those eternal human values, but also returning to humane theater. In the third place, through Schumann's work, we will show how the external theatrical reality intertwines with the internal one as a feature of strong political engagement.

Keywords: contemporary theater; Delbono; Strehler; Schumann; theater in war Sarajevo; epic theater; political theater

\section{Adresa autorice}

Author's address

\author{
Aida Čopra \\ Sorbonne Université \\ aidacopra@gmail.com
}

